\title{
Production, Purification and Partial Characterization of Organo-Solvent Tolerant Protease from Newly Isolated Bacillus sp. BBXS-2
}

Abdul Sattar Qureshi ${ }^{1}$, Altaf Ahmed Simair ${ }^{*}$, Chaudhry Haider Ali ${ }^{3}$, Imrana Khushk ${ }^{1}$, Jawaid Ahmed Khokhar ${ }^{1}$, Ayyaz Ahmad $^{4}$, Muhammad Danish ${ }^{5}$ and Changrui Lu²

${ }^{1}$ Institute of Biotechnology and Genetic Engineering, University of Sindh, Jamshoro 76080, Sindh, Pakistan

${ }^{2}$ College of Chemistry, Chemical Engineering and Biotechnology, Donghua University, Shanghai 201620, PR China

${ }^{3}$ Department of Chemical Engineering, University of Engineering \& Technology, KSK Campus, Lahore 54890, Pakistan

${ }^{4}$ Department of Chemical Engineering, Muhammad Nawaz Sharif University of Engineering and Technology, Multan 66000, Punjab, Pakistan

${ }^{5}$ State Environmental Protection Key Laboratory of Environmental Risk Assessment and Control on Chemical Process, East China University of Science and Technology, Shanghai 200237, PR China

"Corresponding author: Altaf Ahmed Simair, College of Chemistry, Chemical Engineering and Biotechnology, Donghua University, Shanghai 201620, PR China, Tel: +86-21-67792740; Fax: +86-21-67792740; E-mail: altafsimair@dhu.edu.cn

Received date: January 12, 2018, Accepted date: February 01, 2018, Published date: February 08, 2018

Copyright: ( 2018 Qureshi AS, et al. This is an open-access article distributed under the terms of the Creative Commons Attribution License, which permits unrestricted use, distribution, and reproduction in any medium, provided the original author and source are credited.

\begin{abstract}
Proteolytic enzymes are applied in various industries such as detergent, leather, food, textile, cosmetics, pharmaceutical, and synthetic biotechnology. To meet commercial needs, microbial strains of high value in terms of cost-effective production have been focused. In this study, thermophilic strain, Bacillus sp. BBXS-2 was activated on simple growth medium and then transferred to Luria Bertani (LB) medium. Maximum protease concentration of 6723 $\mathrm{U} / \mathrm{mL}$ under optimized fermentation conditions (molasses, corn steep liquor, $\mathrm{pH} 9.0$, and $45^{\circ} \mathrm{C}$ ). The results showed, there was no difference observed in bacterial growth and protease titer while replacing yeast extract with corn steep liquor so, in this way, about $90 \%$ cost of nitrogen source can be saved. The extracellular enzyme was purified to homogeneity from cell-free supernatant by ammonium sulphate precipitation followed by dialysis and ion exchange chromatography, recovery yield reduced from 100 to $22 \%$ and purification fold increased from 1 to 9.82 . The enzyme was active in broad $\mathrm{pH}$ and temperature range $8-12 \mathrm{pH}$ and $30-60^{\circ} \mathrm{C}$, with maximum activity at $\mathrm{pH} 10.0$ and $60^{\circ} \mathrm{C}$, respectively. Protease retained more than $90 \%$ activity after incubation at $40^{\circ} \mathrm{C}$ for 2 weeks in the presence of $(40 \%$ $\mathrm{v} / \mathrm{v}$ ) organic solvents including ethanol, methanol, and isopropanol. Overall, research suggests that this strain is a more promising candidate and possess practical ability to use in industries.
\end{abstract}

Keywords: Bacillus sp. BBXS-2; Corn steep liquor; Organic solvent; Tolerant protease; Molasses; Purified protease

\section{Introduction}

Proteases are applied in several industries, including detergent, leather, food, textile, cosmetics, pharmaceutical, and synthetic biotechnology $[1,2]$. Proteases are major industrial enzymes that accounts for $60 \%$ of the total enzyme sale, and a major proportion of proteases is produced from microorganisms [3]. Among available proteases, many are produced from Bacillus species perhaps due to simple medium and growth conditions requirements, extracellular secretion of enzymes, rapid cell growth, and availability of fully sequenced genome [4]. Several Bacillus species are exploited for extracellular protease including, Bacillus subtilis EFRL 01 [5], Bacillus licheniformis [6-8], B. pseudofirmus [9] and other Bacillus sp. [10]. However, the search of new bacterial strains for protease production with unique properties such as organic solvent tolerant microbes and enzymes, alkaline $\mathrm{pH}$ stability, thermostability, stability in the presence of a surfactant, bleaching and oxidizing agents is continued.

Enzymatic reactions in the presence of organic solvents provide various industrially important benefits, for example, enhanced nonpolar substrates solubility, inhibition or decrease of waterdependent side reactions and controlling the microbial contamination [11-13]. Synthetic biology applications need protease stable active in the organic solvents for a longer duration. Organic solvent tolerant proteases are produced by several bacterial species, including Pseudomonas [14-21], Enterobacter [22], Rhodococcus [23], and Geomicrobium [24]. However, only a few studies are available on organo-solvent proteases from Bacillus species $[12,13]$. Thus, there is a huge gap to be filled with new organic solvent stable proteases from unique microbial strains to meet increasing demand. To obtain highest protease titer, cultural conditions must be optimized in terms of carbon and nitrogen sources, $\mathrm{pH}$, temperature, inoculum size, and time of incubation $[5,25,26]$. A major difficulty in the commercialization of fermentation processes is the cost of nutrients (carbon and nitrogen sources) and purification. Thus, the use of agroindustrial residue as nutrient source could be a promising solution to dispose of the waste and cost-effective protease production.

Therefore, this research work describes protease production from thermophilic Bacillus sp. BBXS-2 using molasses and corn steep liquor as cost-effective carbon and nitrogen sources. Protease fermentation was also confirmed in a $2 \mathrm{~L}$ conical flask with a titer of $6723 \mathrm{U} / \mathrm{mL}$ under optimized fermentation conditions (molasses, corn steep liquor, $\mathrm{pH} 9.0$, and $45^{\circ} \mathrm{C}$ ). In addition, results show that bacterial growth and protease titer have certainly no difference when yeast extract or corn steep liquor was used as nitrogen source. About $90 \%$ of nitrogen source cost was saved by replacing yeast extract with corn steep liquor. The purified protease of Bacillus sp. BBXS-2 has characterized that displayed excellent characteristics, for instance, stability in alkaline $\mathrm{pH}$, 
Page 2 of 9

thermostability, stability in presence of surfactant, oxidizing and bleaching agents, and tolerance against organic solvents. These results suggest that strain possess practical potential to be used in industrial production units and an enzyme having excellent properties make it suitable for biotechnological applications.

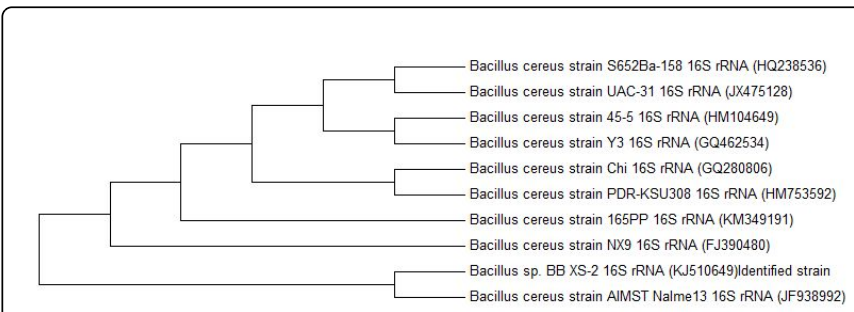

Figure 1: Phylogenetic tree showing the relationship of isolate Bacillus sp. BBXS-2 (KJ510649) to other Bacillus cereus strains values shown in the parenthesis are accession number.

\section{Materials and Methods}

\section{Strain}

Bacillus sp. BBXS-2 was isolated from the soil sample collected from Xuhui district of Shanghai, China. The strain was grown on simple growth medium containing glucose $20 \mathrm{~g} / \mathrm{L}$, peptone $10 \mathrm{~g} / \mathrm{L}$, and sodium chloride $5 \mathrm{~g} / \mathrm{L}$. $\mathrm{pH}$ was adjusted to 7.0 , the culture was incubated for $18 \mathrm{~h}$ at $37^{\circ} \mathrm{C}$ in shaking incubator. This culture was used as inoculum in protease fermentation medium. $16 S$ rRNA gene sequence of the strain was deposited in GenBank database under accession number KJ510649.

\section{Enzyme production}

Bacillus sp. BBXS-2 seed culture was inoculated enzyme production medium composed of glucose $10 \mathrm{~g} / \mathrm{L}$, peptone $5 \mathrm{~g} / \mathrm{L}, \mathrm{MgSO}_{4} \cdot 7 \mathrm{H}_{2} \mathrm{O} 2$ $\mathrm{g} / \mathrm{L}, \mathrm{KH}_{2} \mathrm{PO}_{4} 3 \mathrm{~g} / \mathrm{L}$ and $\mathrm{NaCl} 2 \mathrm{~g} / \mathrm{L}$, as described elsewhere [5]. The culture was incubated in shaking incubator for $120 \mathrm{~h}$ at $37^{\circ} \mathrm{C}$ and samples were harvested after every $12 \mathrm{~h}$ for growth and enzyme production. The cell-free clear sample was collected after centrifugation at $11,300 \times \mathrm{g}$ for $10 \mathrm{~min}$ and used for biochemical analysis by spectrophotometric methods.

\section{Effect of carbon and nitrogen sources}

Effect of various carbon sources, for instance, glucose, molasses, starch, maltose, galactose, fructose, mannose, lactose, sucrose, and xylose $(10 \mathrm{~g} / \mathrm{L})$ for bacterial growth and protease yield was analyzed. To investigate the effect of nitrogen sources, production medium was supplemented $(5 \mathrm{~g} / \mathrm{L})$ with either of peptone, yeast extract, urea, casein, meat extract, tryptone, ammonium chloride, ammonium nitrate, and ammonium sulphate. The culture was incubated in an orbital shaking incubator at $37^{\circ} \mathrm{C}, 150 \mathrm{rpm}$, and $\mathrm{pH} 7.0$ for $48 \mathrm{~h}$.

\section{Influence of $\mathrm{pH}$ and temperature on protease production}

Bacillus sp. BBXS-2 was grown in a fermentation medium with different initial $\mathrm{pH}$ ranging from 5.0-12.0 adjusted with 2.0 $\mathrm{M} \mathrm{H}_{2} \mathrm{SO}_{4}$ or $5.0 \mathrm{M} \mathrm{NaOH}$. For evaluating the effect of temperature on bacterial growth and protease titer, Bacillus sp. BBXS-2 was cultivated in shaking incubator at a different temperature range of $30-55^{\circ} \mathrm{C}, \mathrm{pH} 10.0$ for $48 \mathrm{~h}$.

\section{Evaluation of corn steep liquor as cost-effective nutrient}

The different initial concentrations of corn steep liquor $(0,5,10,20$, $30,40 \mathrm{~g} / \mathrm{L}$ ) were added to optimize fermentation medium instead of yeast extract.

\section{Protease assay}

Protease production was monitored according to the following method adapted from [27]. $0.5 \mathrm{~mL}$ of the appropriately diluted enzyme was added in $0.5 \mathrm{~mL}$ of a casein solution $(10 \mathrm{~g} / \mathrm{L}$, adjusted to $\mathrm{pH} 10.0)$ and $1.5 \mathrm{~mL}$ of glycine- $\mathrm{NaOH}$ buffer $(\mathrm{pH} 10.0)$. The reaction mixture was kept at $60^{\circ} \mathrm{C}$ for $30 \mathrm{~min}$ in a shaking water bath. $2 \mathrm{~mL}$ of sample was removed at the end of the reaction and quenched at once by mixing with $2 \mathrm{~mL}$ of trichloroacetic acid $(15 \mathrm{~g} / \mathrm{L})$. The mixture was centrifuged at $4000 \times \mathrm{g}$ for $10 \mathrm{~min}$ to remove the protein precipitate, whereas $1 \mathrm{~mL}$ of the (supernatant) sample was mixed with $4 \mathrm{~mL}$ of 0.5 $\mathrm{M} \mathrm{NaOH}, 1 \mathrm{~mL}$ of Folin phenol reagent and $4 \mathrm{~mL}$ of double distilled water. Absorbance was detected at $625 \mathrm{~nm}$ against an appropriate substrate and enzyme blank. The difference in absorbance between the initial reaction mixture and the sample was taken at $30 \mathrm{~min}$, indicated the proteolytic activity in terms of released tyrosine. The standard graph for calculating protease concentration was prepared with 10-50 $\mu \mathrm{g} / \mathrm{mL}$ of tyrosine solutions. One unit of protease activity was defined as the amount of protease that liberated $1 \mu \mathrm{mol}$ of tyrosine under the assay conditions.

\section{Confirmation experiment in $2 \mathrm{~L}$ conical flask}

Protease fermentation was performed in $2 \mathrm{~L}$ conical flask to scale up the protease production from the new thermophilic strain, experiments were conducted in parallel. $18 \mathrm{~h}$ old seed culture of Bacillus sp. BBXS-2 at the rate of $10(\% \mathrm{v} / \mathrm{v})$ was transferred as inoculum to enzyme production medium and culture was incubated at $45^{\circ} \mathrm{C}$ for $48 \mathrm{~h}$ in constant shaking conditions, $\mathrm{pH}$ was adjusted to 9.0. Samples were collected at regular interval for monitoring the bacterial growth and protease activity.

\section{Protease purification and characterization}

Cell-free clear liquid (culture broth) was precipitated by addition of ammonium sulphate (30-100\%), with optimum precipitation at $75 \%$. The fraction was obtained by centrifugation at $10,000 \mathrm{~g}$ for $10 \mathrm{~min}$. Precipitates were dissolved in $20 \mathrm{mM}$ Tris- $\mathrm{HCl}$ buffer ( $\mathrm{pH} 8.0$ ). Dialysis was applied to the collected extract then, undissolved proteins were removed by centrifugation at $11,300 \times \mathrm{g}$ for $5 \mathrm{~min}$. Clear supernatant $10 \mathrm{~mL}$ was applied to ion exchange column and equilibrated with $10 \mathrm{mM}$ Tris- $\mathrm{HCl}$ buffer ( $\mathrm{pH}$ 8.0). Protein samples were measured at $280 \mathrm{~nm}$ and protease activity was checked according to the method described in materials and methods section, and then enzyme bands were analyzed on SDS-PAGE.

To monitor $\mathrm{pH}$ optimum for protease activity with a maximal substrate, the conversion was investigated by incubating reaction mixture at different $\mathrm{pH}$ range 6.0-12.0. Following buffer solutions were used for changing $\mathrm{pH}$ values: phosphate buffer $\mathrm{pH}$ 6.0-7.5; Tris- $\mathrm{HCl}$ buffer $\mathrm{pH}$ 8.0-8.5; glycine-NaOH buffer $\mathrm{pH}$ 9.0-12.0. Protease stability at different $\mathrm{pH}$ values $(6.0-12.0 \mathrm{pH})$ was monitored by placing purified enzyme different buffer solutions at $35^{\circ} \mathrm{C}$ for $1 \mathrm{~h}$, and the protease 
Page 3 of 9

activity was measured under assay conditions. The optimum temperature for the maximal catalytic reaction was checked by determining protease activity at different temperature ranges $\left(30-85^{\circ} \mathrm{C}\right)$ at fixed $\mathrm{pH}$ and substrate concentration for $30 \mathrm{~min}$. Thermostability was monitored prior to incubate enzyme solution for 1 $\mathrm{h}$ at different temperature ranges $30-85^{\circ} \mathrm{C}$. Metal ions influence on protease activity was monitored by pre-incubating enzyme with 12 $\mathrm{mM}$ of these metal ions $\left(\mathrm{Ca}^{2+}, \mathrm{Zn}^{2+}, \mathrm{Co}^{2+}, \mathrm{Fe}^{2+}, \mathrm{Ni}^{2+}, \mathrm{Mg}^{2+}\right)$ at the concentration of $12 \mathrm{mM}$.

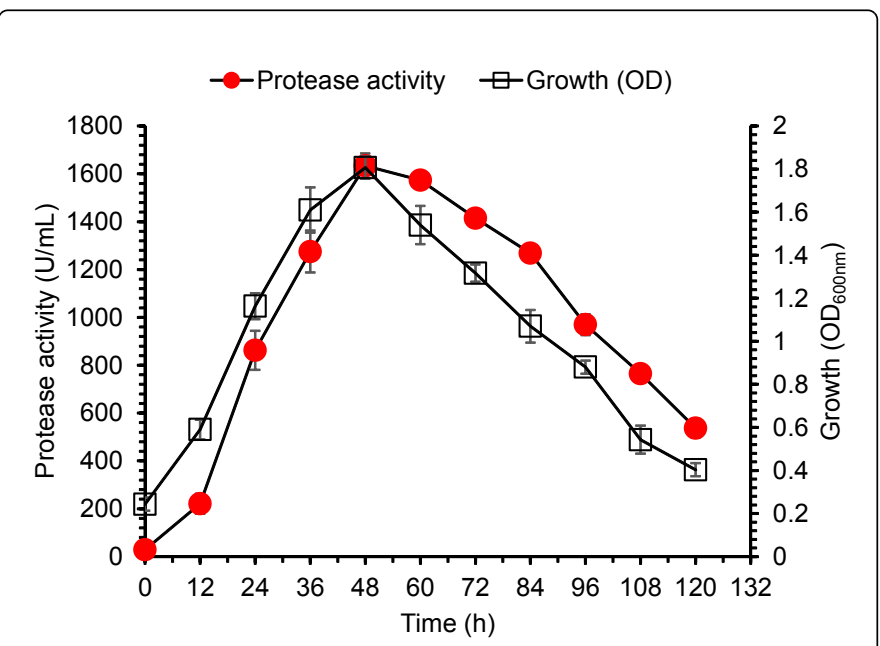

Figure 2: Batch profile of protease titer and bacterial growth in basal medium containing $(\mathrm{g} / \mathrm{L})$ glucose 10 , peptone $5, \mathrm{MgSO}_{4} \cdot 7 \mathrm{H}_{2} \mathrm{O} 2$, $\mathrm{KH}_{2} \mathrm{PO}_{4} 3$ and $\mathrm{NaCl} 2$ and incubated in an orbital shaking incubator at $37^{\circ} \mathrm{C}$ with initial $\mathrm{pH}$ 7.0. Results are the average of a triplicate experiment.

\section{Enzyme stability in surfactant, oxidizing and bleaching agents}

For applicability of protease in biotechnology industries (synthetic biotechnology, detergent industry, and leather industry) its stability in the presence of organic solvents, surfactants, oxidizing, and bleaching agents was determined. Protease stability was measured by incubating enzyme in presence of different organic solvents $(40 \% \mathrm{v} / \mathrm{v})$, including ethanol, methanol, isopropanol, acetone, toluene, n-hexane, xylene, and DMSO for 2 weeks at $40^{\circ} \mathrm{C}$ in shaking incubator. Stability of protease was assayed in presence of Triton X-100, Tween 80, SDS (surfactants), $\mathrm{H}_{2} \mathrm{O}_{2}$ (oxidizing agent), and sodium hypochlorite (bleaching agent). Residual activity was determined under optimized assay conditions ( $\mathrm{pH} 10.0$ and $40^{\circ} \mathrm{C}$ ). Protease activity was measured as $\%$ of relative activity as compared to control (without additives) that was taken as $100 \%$.

\section{Accession number}

The genome sequence data have been deposited in GenBank under accession number KJ510649.

\section{Statistical analysis}

Three replicates of each sample were used for statistical analysis. Data were reported as means \pm S.D. Analysis of variance and least significant difference tests were conducted to identify differences among means. t-test was performed to determine significant differences at $\mathrm{p}<0.05$.

\section{Results}

\section{Screening, isolation, and identification of protease producing strain}

In the present study, 33 bacterial strains were isolated from soil samples of Xuhui, Shanghai, China and were screened for proteolytic activity using casein agar medium and clear zone of proteolysis was detected on the casein agar plates. Among these strains with larger zone were selected for further confirmation of extracellular protease activity in fermentation medium (data not shown). Finally, a strain that performed well in plates and liquid fermentation was identified as a member of the genus Bacillus behalf of $16 S \mathrm{rRNA}$ gene sequence similarity. The nucleotide sequence (KJ510649) reported here has been assigned from NCBI GenBank database. The phylogenetic tree was plotted by comparing the gene sequences of earlier submitted data using molecular evolutionary genetics analysis (MEGA-6) [28], and a phylogenetic tree is shown in Figure 1.

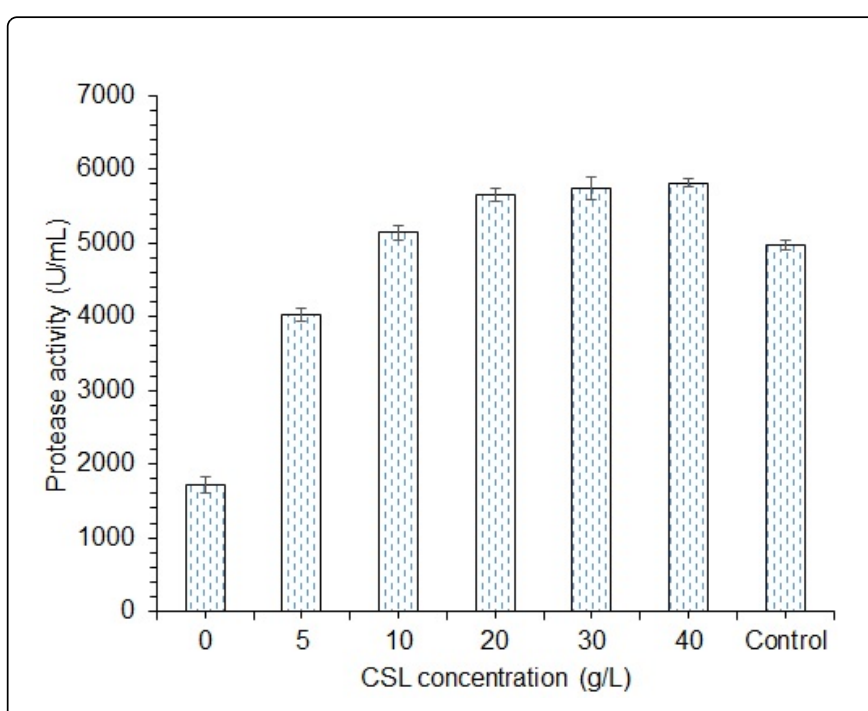

Figure 3: Effect of corn steep liquor (CSL) concentration $(0,5,10$, $20,30,40 \mathrm{~g} / \mathrm{L})$ on protease production under optimized conditions (48 h, molasses, $9.0 \mathrm{pH}$, and $\left.45^{\circ} \mathrm{C}\right)$. The control experiment was designed to compare the efficiency of CSL with yeast extract $(5 \mathrm{~g} / \mathrm{L})$. In the control all other conditions were same. Results are the average of triplicate experiments.

\section{Optimization of fermentation conditions for protease production}

A time course of protease concentration and bacterial growth was developed for newly isolated Bacillus sp. BBXS-2 in basal medium containing: $10 \mathrm{~g} / \mathrm{L}$ of glucose, $5 \mathrm{~g} / \mathrm{L}$ of peptone, $2 \mathrm{~g} / \mathrm{L}$ of $\mathrm{MgSO}_{4}, 3 \mathrm{~g} / \mathrm{L}$ of $\mathrm{KH}_{2} \mathrm{PO}_{4}$, and $2 \mathrm{~g} / \mathrm{L}$ of $\mathrm{NaCl}$ (Figure 2). Maximum protease yield of $2060 \mathrm{U} / \mathrm{mL}$ obtained when molasses was supplemented as sole carbon source compared to other pure sugars, results are shown in Table 1. 
Citation: Qureshi AS, Simair AA, Ali CH, Khushk I, Khokhar JA, et al. (2018) Production, Purification and Partial Characterization of OrganoSolvent Tolerant Protease from Newly Isolated Bacillus sp. BBXS-2. Ferment Technol 7: 151. doi:10.4172/2167-7972.1000151

Page 4 of 9

\begin{tabular}{|c|c|c|c|c|c|c|c|c|c|c|}
\hline Carbon source & Glucose & Molasses & Maltose & Galactose & Fructose & Mannose & Starch & Lactose & Xylose & Sucrose \\
\hline Protease activity & 1450 & 2060 & 1622 & 1488 & 1245 & 1109 & 1886 & 1423 & 1125 & 1624 \\
\hline Absorbance $600 \mathrm{~nm}$ & 1.82 & 2.23 & 1.65 & 1.21 & 1.38 & 1.91 & 1.22 & 1.17 & 1.09 & 1.54 \\
\hline Nitrogen source & Peptone & $\begin{array}{l}\text { Yeast } \\
\text { extract }\end{array}$ & Urea & Casein & $\begin{array}{l}\text { Meat } \\
\text { extract }\end{array}$ & Tryptone & $\begin{array}{l}\text { Ammonium } \\
\text { chloride }\end{array}$ & $\begin{array}{l}\text { Ammonium } \\
\text { nitrate }\end{array}$ & $\begin{array}{l}\text { Ammonium } \\
\text { sulphate }\end{array}$ & \\
\hline Protease activity & 2060 & 2579 & 979 & 1664 & 1739 & 1452 & 928 & 814 & 657 & \\
\hline Absorbance $600 \mathrm{~nm}$ & 2.25 & 2.52 & 0.98 & 1.31 & 1.32 & 1.13 & 0.98 & 0.72 & 0.82 & \\
\hline $\mathrm{pH}$ & 5 & 6 & 7 & 8 & 9 & 10 & 11 & 12 & & \\
\hline Protease activity & 1094 & 1588 & 2579 & 3070 & 3260 & 2938 & 2650 & 2346 & & \\
\hline Absorbance $600 \mathrm{~nm}$ & 1.14 & 1.53 & 2.57 & 2.72 & 3.19 & 2.67 & 1.96 & 1.83 & & \\
\hline Temperature & 30 & 37 & 40 & 42 & 45 & 48 & 50 & 55 & & \\
\hline Protease activity & 2386 & 3260 & 3746 & 4321 & 4974 & 4841 & 4421 & 3623 & & \\
\hline Absorbance $600 \mathrm{~nm}$ & 2.71 & 3.12 & 3.20 & 3.47 & 3.59 & 3.37 & 3.14 & 2.75 & & \\
\hline
\end{tabular}

Conditions for carbon sources effect $(10 \mathrm{~g} / \mathrm{L})$ on protease titer and bacterial growth at $48 \mathrm{~h}$ of fermentation $\left(37^{\circ} \mathrm{C}\right.$, initial $\mathrm{pH}$ of 7.0$)$. Conditions for nitrogen sources effect $(5 \mathrm{~g} / \mathrm{L})$ on protease production and cell growth at $48 \mathrm{~h}$ of fermentation $\left(37^{\circ} \mathrm{C}\right.$, initial $\mathrm{pH}$ of 7.0$)$ in a molasses $(10 \mathrm{~g} / \mathrm{L}$ initial concentration) mineral medium. Conditions for initial $\mathrm{pH}$ effect on protease fermentation and microbial growth for $48 \mathrm{~h}$ at $\left(37^{\circ} \mathrm{C}\right)$ in a mineral medium containing molasses and yeast extract as carbon and nitrogen sources, respectively. Conditions for the influence of temperature on protease production and bacillus growth at $48 \mathrm{~h}$. The medium initially contained 10 $\mathrm{g} / \mathrm{L}$ molasses and $5.0 \mathrm{~g} / \mathrm{L}$ yeast extract and initial $\mathrm{pH}$ was adjusted to 9 . Results are the average of a triplicate experiment.

Table 1: Optimization of cultural conditions for protease production (U/mL) from Bacillus sp. BBXS-2.

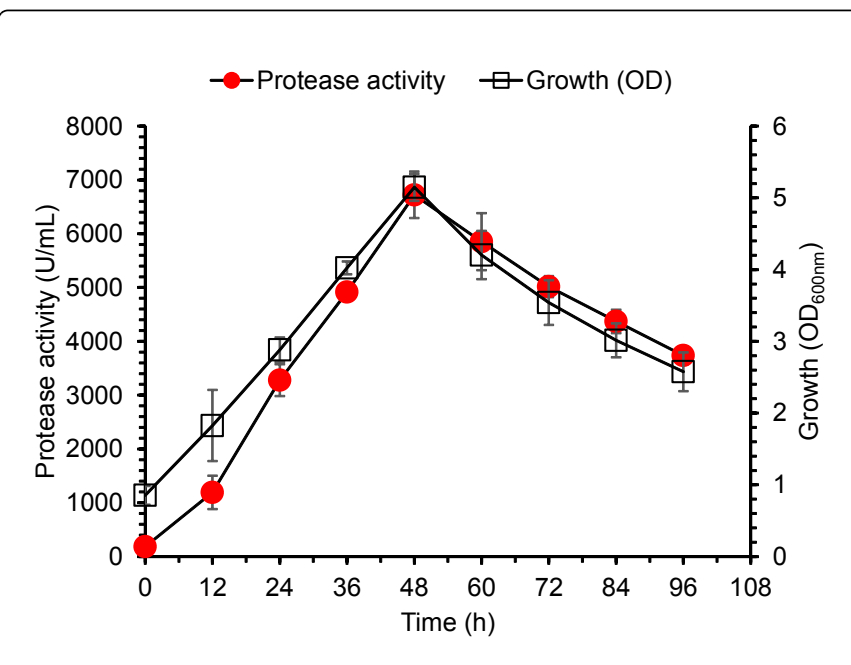

Figure 4: Confirmation experiment for protease production using optimized medium and cultural conditions in a $2 \mathrm{~L}$ conical flask. Molasses and corn steep liquor were used as sole carbon and nitrogen source. The culture was incubated at $45^{\circ} \mathrm{C}$ for $96 \mathrm{~h}, \mathrm{pH}$ was adjusted to 9.0. Results are average of a triplicate experiment. Error bars are shown for standard deviation.

Effect of organic and inorganic nitrogen sources was evaluated on cell growth and protease production. Highest enzyme yield obtained when yeast extract $(2579 \mathrm{U} / \mathrm{mL})$ used followed by peptone $(2060$ $\mathrm{U} / \mathrm{mL})$ and meat extract $(1736 \mathrm{U} / \mathrm{mL})$ was used. Inorganic nitrogen source showed lowest protease titer, perhaps due to reduced cell growth, results are shown in Table 1 . Effect of initial $\mathrm{pH}$ on the protease titer and growth of Bacillus sp. BBXS-2 is shown in Table 1. Initial $\mathrm{pH}$ of the medium was adjusted in the range of 5.0-12.0 before sterilization of medium. The culture was inoculated in each flask then, incubated at $37^{\circ} \mathrm{C}$ for $48 \mathrm{~h}$ in shaking incubator. Maximum protease activity $(3260 \mathrm{U} / \mathrm{mL})$ was obtained at initial $\mathrm{pH}$ of 9.0 , it indicates the alkaliphilic nature of strain. Generally, the microbial strain could grow in alkaline $\mathrm{pH}$ range are very important due to increasing demands of alkaline stable enzymes. Literature reports that alkaline stable proteases are applied in detergent and leather industries.

Further, an effect of temperature $\left(30\right.$ to $\left.55^{\circ} \mathrm{C}\right)$ on enzyme production and growth of Bacillus sp. BBXS-2 was studied. Protease titer increased with increasing temperature and reached maximum to $4974 \mathrm{U} / \mathrm{mL}$ at $45^{\circ} \mathrm{C}$. Further increase in temperature reduced protease concentration perhaps due to the decrease in cell growth, results are shown in Table 1.

\section{Evaluation of corn steep liquor (CSL) as cost-effective nitrogen source}

In routine fermentation experiments, at a laboratory and industrial scale, yeast extract (YE) and or peptone are used as nitrogen source but due to increasing nutrients cost, inexpensive nitrogen sources are certainly required to increase the economic viability of commercial enzyme production. Therefore, in this study, the efficiency of corn steep liquor (CSL) as nitrogen source was investigated. Corn steep liquor at various concentrations $(0,5,10,2030,40 \mathrm{~g} / \mathrm{L})$ were supplemented in the fermentation medium and results were compared with control (yeast extract $5 \mathrm{~g} / \mathrm{L}$ ). Maximum protease titer was observed when $20 \mathrm{~g} / \mathrm{L}$ of CSL used, there was no significant increase in the protease concentration when 30 and $40 \mathrm{~g} / \mathrm{L}$ of CSL used. Protease concentrations were $(5654 \mathrm{U} / \mathrm{mL})$ and $(4974 \mathrm{U} / \mathrm{mL})$ in case of CSL and 
Citation: Qureshi AS, Simair AA, Ali CH, Khushk I, Khokhar JA, et al. (2018) Production, Purification and Partial Characterization of OrganoSolvent Tolerant Protease from Newly Isolated Bacillus sp. BBXS-2. Ferment Technol 7: 151. doi:10.4172/2167-7972.1000151

Page 5 of 9

yeast extract, respectively, results are shown in Figure 3. The price of yeast extract is $9.2 \$ / \mathrm{kg}$ equivalent to $9,200 \$ /$ ton and that of CSL is $0.18 \$ / \mathrm{kg}$ equivalent to $180 \$ /$ ton as reported elsewhere [29]. Results clearly showed the significance of our study to reduce enzyme production cost using CSL and molasses as nitrogen and carbon sources.

\begin{tabular}{|c|c|c|c|c|c|}
\hline Purification step & Total activity (U) & Total Protein $(\mathrm{mg})$ & $\begin{array}{l}\text { Specific activity } \\
\text { (U/mg protein) }\end{array}$ & Purification fold & Yield (\%) \\
\hline Crude & 5654 & 63 & 89.74 & 1 & 100 \\
\hline Ammonium sulphate precipitation & 2945 & 18 & 163.61 & 1.82 & 52.08 \\
\hline Dialysis & 2004 & 8 & 250.5 & 2.79 & 35.44 \\
\hline ion exchange chromatography & 1234 & 1.4 & 881.42 & 9.82 & 21.82 \\
\hline
\end{tabular}

Table 2: Purification of protease produced from Bacillus sp. BBXS-2.

In the next step, confirmation experiment for protease production in $2 \mathrm{~L}$ conical flask was performed and $6723 \mathrm{U} / \mathrm{mL}$ of protease was obtained as shown in Figure 4, and $5654 \mathrm{U} / \mathrm{mL}$ protease activity was noted in $250 \mathrm{~mL}$ conical flask containing $50 \mathrm{~mL}$ of fermentation medium at the end of $48 \mathrm{~h}$ with 1.18-fold increase in protease titer at large scale fermentation. Previous studies have also reported similar pattern for scaling up studies. Thus, the strain shows great potential to be applied for large-scale protease production.

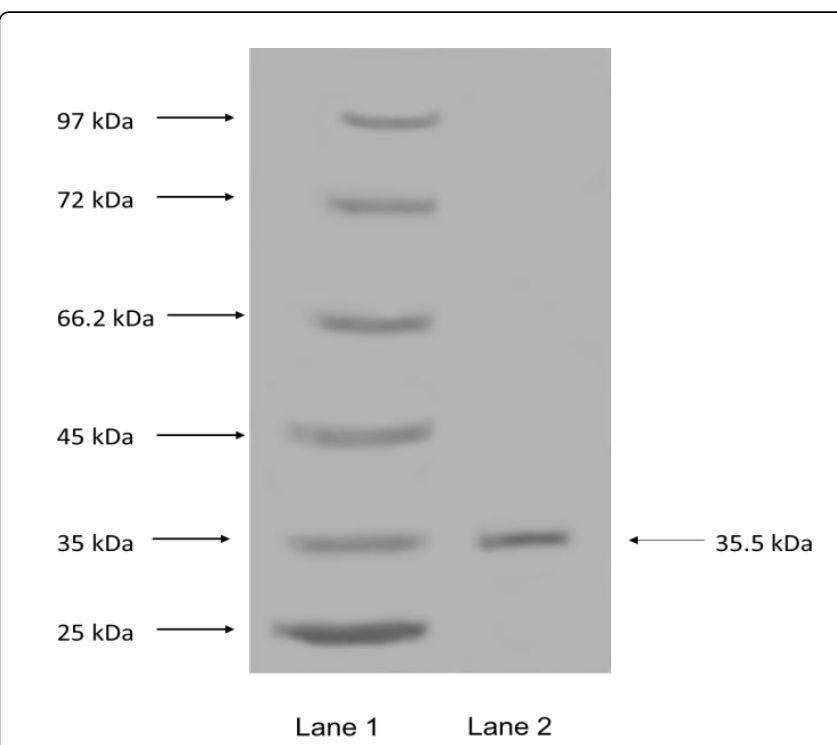

Figure 5a: SDS-PAGE, (Lane 1) Standard protein marker (97.0 kDaPhosphorylase; $66.2 \mathrm{kDa}$-Bovine serum albumin (BSA); $45.0 \mathrm{kDa}-$ Ovalbumin; $35.0 \mathrm{kDa}$-Lactate dehydrogenase; $25.0 \mathrm{kDa}$-REase Bsp981, (Lane 2) Purified protease from Bacillus sp. BBXS-2.

\section{Enzyme purification and characterization of the protease of Bacillus sp. BBXS-2}

Cell-free clear solution (fermentation broth) was used for ammonium sulphate precipitation (30-100\%) showed protease activity at $75 \%$ saturation with 1.82 -fold purification, then precipitates were dissolved in $20 \mathrm{mM}$ Tris- $\mathrm{HCl}$ buffer ( $\mathrm{pH}$ 8.0). Then enzyme buffer mixture was dialyzed and finally partially purified sample with 2.79fold purification and $35.44 \%$ yield was subjected to ion exchange chromatography. Enzyme purification fold increased to 9.82 with $21.82 \%$ yield. Finally, purified enzyme was loaded on the SDS-PAGE gel to checking homogeneity and a single band of $35.5 \mathrm{kDa}$ was obtained (Figure 5a). Purification steps from culture both to final products are detailed in Table 2.

\begin{tabular}{|l|l|}
\hline Surfactant & Protease activity (\%) \\
\hline Triton $\mathrm{X}-100(0.5 \% \mathrm{v} / \mathrm{v})$ & $115.2 \pm 1.9$ \\
\hline Tween-80 $(1.0 \% \mathrm{v} / \mathrm{v})$ & $110.6 \pm 1.4$ \\
\hline $\mathrm{SDS}(0.5 \% \mathrm{v} / \mathrm{v})$ & $142.2 \pm 1.1$ \\
\hline SDS $(1.0 \% \mathrm{v} / \mathrm{v})$ & $133.1 \pm 2.4$ \\
\hline H2O2 $(1.0 \% \mathrm{v} / \mathrm{v})$ & $105.1 \pm 2.2$ \\
\hline Sodium hypochlorite $(1.0 \% \mathrm{v} / \mathrm{v})$ & $111.1 \pm 1.7$ \\
\hline Control & 100 \\
\hline Organic Solvent & \\
\hline Ethanol & $96.6 \pm 1.4$ \\
\hline Methanol & $93.27 \pm 2.2$ \\
\hline Isopropanol & $90.33 \pm 1.4$ \\
\hline Toluene & $86.6 \pm 1.9$ \\
\hline Xylene & $81.8 \pm 1.7$ \\
\hline $\mathrm{n}-$ Hexane & $65.3 \pm 1.9$ \\
\hline DMSO & $54.1 \pm 2.5$ \\
\hline Acetone & $81.1 \pm 2.4$ \\
\hline Metal lons & $124.2 \pm 1.9$ \\
\hline Mg ${ }^{2+}$ & $146.4 \pm 1.5$ \\
\hline Ca ${ }^{2+}$ & $112.1 \pm 1.2$ \\
\hline Fe ${ }^{2+}$ & $24.5 \pm 2.7$ \\
\hline Zn ${ }^{2+}$ & $41.3 \pm 1.4$ \\
\hline Co ${ }^{2+}$ & $55.3 \pm 2.5$ \\
\hline $\mathrm{Ni}^{2+}$ & \\
\hline
\end{tabular}


Page 6 of 9

Conditions: Preincubation $\left(1 \mathrm{~h}, 40^{\circ} \mathrm{C}, \mathrm{pH}\right.$ of 10$)$ of the purified enzyme with various metals $(12 \mathrm{mM})$, organic solvents $(40 \% \mathrm{v} / \mathrm{v})$, and surfactant on protease activity $(1.0 \% \mathrm{v} / \mathrm{v})$. The reaction was incubated at $40^{\circ} \mathrm{C}$ for $1 \mathrm{~h}$ in glycine- $\mathrm{NaOH}$ buffer ( $\mathrm{pH} 10)$. Results are shown as a percentage of relative activity comparing to that of control (no additive). Results are average of triplicate experiments.

Table 3: Effect of different metal ions $(12 \mathrm{mM})$, detergents and oxidizing agents $(1 \%)$, and organic solvents $(40 \% \mathrm{v} / \mathrm{v})$ on the activity of protease from Bacillus sp. after $1 \mathrm{~h}$ at $40^{\circ} \mathrm{C}$.

Characterization of an enzyme is significantly important for applications and enzyme stability in terms of $\mathrm{pH}$, temperature, surfactants, oxidizing and bleaching agents, and organic solvents is required for the local detergents formulations, leather industry, and synthetic biotechnology. Optimum $\mathrm{pH}$ for enzyme activity was checked at different $\mathrm{pH}$ values $(6.0-12.0)$, casein used as substrate and reaction was incubated at $35^{\circ} \mathrm{C}$, results are shown in Figure $5 \mathrm{~b}$. Protease activity increased till $\mathrm{pH}(10.0)$ and then showed a gradual decrease as $\mathrm{pH}$ increased. Moreover, protease remained stable in broad $\mathrm{pH}$ range of (8.0-12.0) with maximum activity at $\mathrm{pH}(10.0)$. However, maximum enzyme activity (75.91\%) was achieved at $\mathrm{pH}(12.0)$ as shown in Figure 5b.

On the other hand, maximum protease activity appeared at $60^{\circ} \mathrm{C}$, as shown in Figure $5 \mathrm{c}$. The relative activities at 30 and $70^{\circ} \mathrm{C}$ were about 39.45 and $69.66 \%$, respectively. The enzyme was thermo-stable in the range of $25-60^{\circ} \mathrm{C}$ and retained $95.22,75.46$ and $26.67 \%$ initial activity after $1 \mathrm{~h}$ incubation at 60,70 and $80^{\circ} \mathrm{C}$, respectively as shown in Figure 5 c.

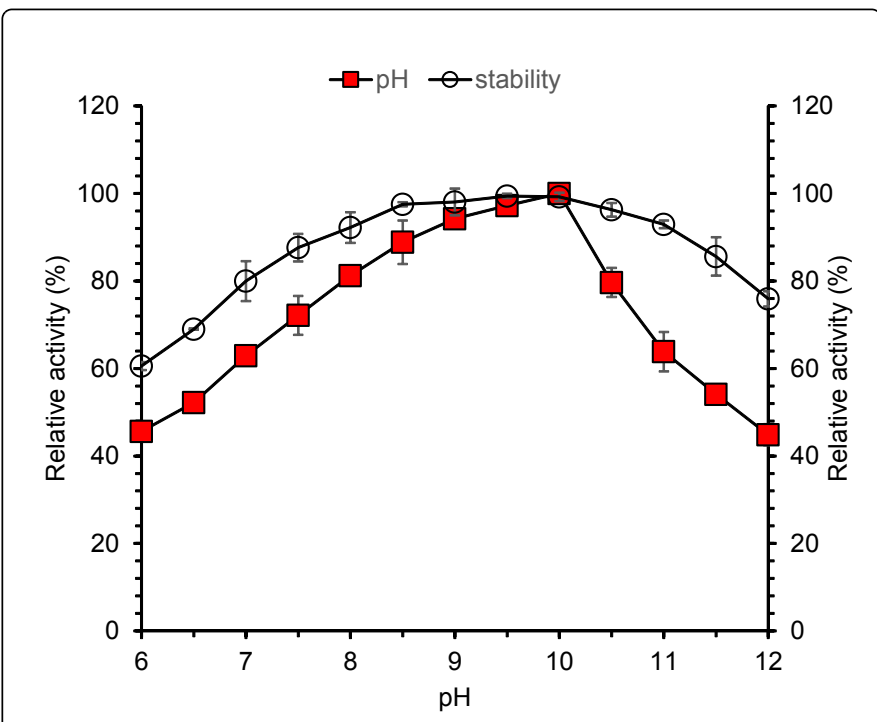

Figure 5b: Effect of $\mathrm{pH}$ on protease activity and stability. For evaluating $\mathrm{pH}$ activity, a percentage of relative activity was measured by incubating enzyme with the substrate at different $\mathrm{pH}$ values (6.0-12.0). Buffers used are: $\mathrm{pH}$ stability of purified protease was determined by measuring protease activity. The purified enzyme was incubated for $1 \mathrm{~h}$, at specified $\mathrm{pH}$ values (abovementioned buffers) at $35^{\circ} \mathrm{C}$, prior addition of substrate, and\% of relative activity was determined. Results are the average of a triplicate experiment.

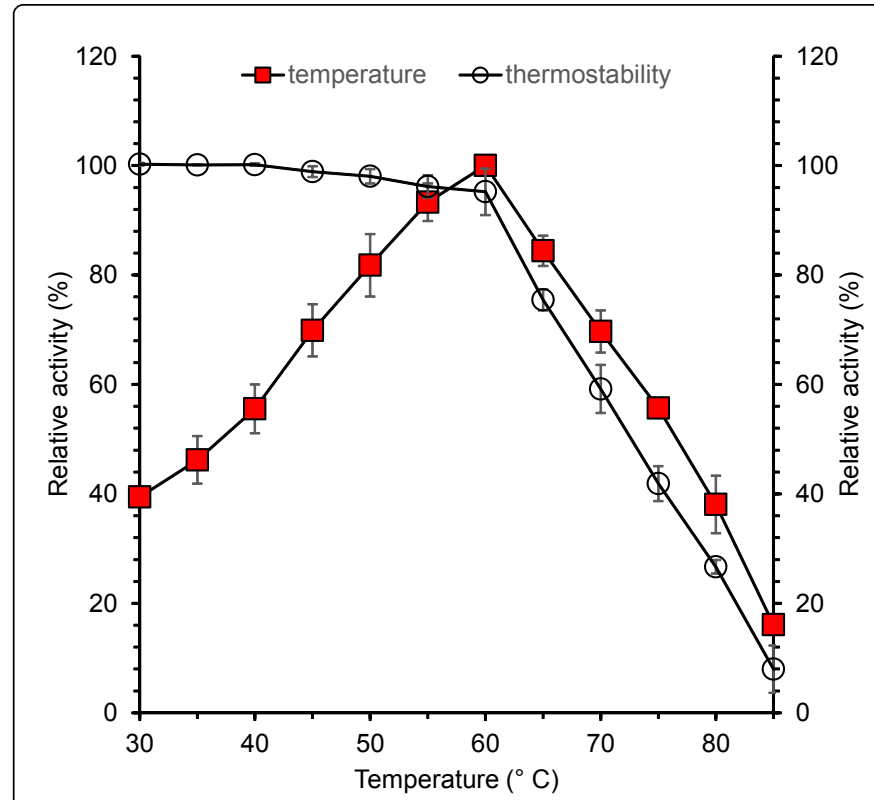

Figure 5c: Effect of temperature on protease activity. The enzyme was mixed with the substrate and incubated at different temperature for $30 \mathrm{~min}$. \% of relative activity was measured under assay conditions. Thermostability of protease was determined by incubating enzyme at different temperature without the addition of substrate for $1 \mathrm{~h}$. Percentage of relative activity was checked under assay conditions. Results are the average of a triplicate experiment.

The protease was stable against all surfactants especially, SDS $(0.5 \%$ $\mathrm{v} / \mathrm{v}$ ) that increased to $142.2 \%$ when treated at $40^{\circ} \mathrm{C}$. However, with SDS $(1.0 \% \mathrm{v} / \mathrm{v})$ it reduced to $133.1 \%$ (Table 3$)$. Protease relative activity was enhanced by the addition of all tested surfactant, oxidizing, and bleaching agent that obviously indicate the suitability of protease for detergent applications. Table 3 shows that alkaline protease is stable in the presence of various solvents $(40 \% \mathrm{v} / \mathrm{v})$. The protease was found stable in presence of several organic solvents, with maximal activity (98\%) in the presence of $40(\% \mathrm{v} / \mathrm{v})$ ethanol after 2 weeks of incubation at $40^{\circ} \mathrm{C}$ compared to control. In addition, our protease was stable at high temperature and $\mathrm{pH}$.

In addition to solvent tolerability, protease activity was evaluated with different metal ions (Table 3). Protease activity increased with addition of $\mathrm{Ca}^{2+}, \mathrm{Mg}^{2+}$ and $\mathrm{Fe}^{2+}$ to $46.4 \%, 24.2 \%$ and $11.2 \%$, respectively. Whereas, protease activity was significantly reduced by addition of $\mathrm{Zn}^{2+}, \mathrm{Co}^{2+}$, and $\mathrm{Ni}^{2+}$ compared to control (Table 3). Unique characteristics of protease: stability in surfactants, bleaching agent, alkaline $\mathrm{pH}$, and high temperature make it suitable candidature in biotechnological applications.

\section{Discussion}

In our study, more than thirty bacterial strains were isolated and screened for proteolytic activity using casein agar plates. Some of these strains showed protease activity with clear zone formation, then strain with larger zone was identified as a member of the genus Bacillus on behalf of $16 S \mathrm{rRNA}$ gene sequence similarity, nucleotide sequence was submitted to NCBI GenBank database with the accession number of KJ510649. Zone formation was due to proteolytic activity of microbial 
strains, size of zone was directly related to enzyme secretion. Protease titer increased with the passage of time reached to maximum level after $48 \mathrm{~h}$ of incubation then gradually decreased. These results were in line with Ibrahim et al. [30], as they attained maximum protease titer after $36 \mathrm{~h}$ from Bacillus sp. NPST-AK-15. In addition to protease activity and microbial growth, total sugar, total protein, and final $\mathrm{pH}$ were also determined (data not shown). It was noted that final $\mathrm{pH}$ reduced with the passage of time perhaps due to formation and accumulation of organic acid. This could also be a reason for reduced growth with the time of incubation. Glucose is commonly used as carbon source in growth and fermentation media but increasing demands of fermented products and cost of pure sugars has compelled researchers to search for new cost-effective and abundant energy sources. However, several researchers have exploited waste residues: olive pomace for lipase production, agricultural waste for protease production, feather waste for protease production, and corn stover for ethanol production [31-34].

\begin{tabular}{|c|c|c|c|}
\hline Strain & Carbon source & Nitrogen source & Reference \\
\hline Bacillus licheniformis YP1A & Starch $5 \mathrm{~g} / \mathrm{L}$ & $\begin{array}{l}\text { Yeast extract } 1.0 \mathrm{~g} / \mathrm{L}+\text { Degossy cotton seed meal } 5.0 \\
\mathrm{~g} / \mathrm{L}\end{array}$ & [13] \\
\hline Kluyveromyces marxianus IFO 0288 & Glucose $10 \mathrm{~g} / \mathrm{L}$ & YNB $5 \mathrm{~g} / \mathrm{L}+$ Albumin $0.4 \mathrm{~g} / \mathrm{L}$ & [40] \\
\hline Bacillus sp. JER02 & Sucrose $5 \mathrm{~g} / \mathrm{L}+$ Citric acid $5 \mathrm{~g} / \mathrm{L}$ & Yeast extract $10 \mathrm{~g} / \mathrm{L}$ & [12] \\
\hline Bacillus sp. SM2014 & Glucose $0.5 \%$ w/v & Casamino acid $0.5 \% \mathrm{w} / \mathrm{v}+$ Yeast extract $0.5 \% \mathrm{w} / \mathrm{v}$ & [41] \\
\hline Pseudomonas putida SKG-1 & Glucose $10 \mathrm{~g} / \mathrm{L}$ & $\begin{array}{l}\text { Peptone } 10 \mathrm{~g} / \mathrm{L} \\
\text { Yeast extract } 5 \mathrm{~g} / \mathrm{L}\end{array}$ & {$[37]$} \\
\hline Bacillus sp. BBXS-2 & Molasses $10 \mathrm{~g} / \mathrm{L}$ & Corn steep liquor $20 \mathrm{~g} / \mathrm{L}$ & This study \\
\hline
\end{tabular}

Table 4: Comparison of carbon and nitrogen sources used for protease production.

Previous studies have proved the potential of agro-industrial residues as a cost-effective energy source. Therefore, in this study, an efficacy of molasses as carbon source was evaluated. Molasses, industrial residues obtained from sugar industry that contains carbohydrates, proteins, minerals, and growth regulators. Thus, molasses provides sufficient nutrients for better bacterial growth and enzyme production. Microbial growth and protease activity varied with nitrogen sources. No doubt, maximum protease yield attained when the microorganism is grown in mineral medium containing yeast and beef extract as evident from various studies $[35,36]$ but researchers are focusing to utilize inexpensive nitrogen sources like corn step liquor and seed cake. Therefore, we used corn steep liquor as a cost-effective nitrogen source for bacterial growth and protease fermentation. Temperature is one of the important parameters, most of the reported protease work used mesophilic strains, for example, $\mathrm{Li}$ et al. [13] obtained protease from mesophilic Bacillus licheniformis YP1A at $30^{\circ} \mathrm{C}$. Singh et al. [37] produced protease from Pseudomonas putida SKG- 1 at $25^{\circ} \mathrm{C}$. However, thermophilic microorganisms could produce thermostable enzyme at high temperature and this might eliminate the chances of contamination during fermentation. However, isolation of thermophilic microorganisms is certainly required to meet increasing demands for thermostable proteases. Our study provides a suitable source of thermostable protease production from newly isolated thermophilic bacterial strains, this enzyme could be a good candidate for various industrial processes.

From an application point of view protease with better properties in terms of stability in an organic solvent, alkaline $\mathrm{pH}$, and high temperature could be the best choice. Previous studies reported proteases stability at moderate organic solvent concentration $20-25 \%$ $\mathrm{v} / \mathrm{v}$ [37-41]. However, our results are showing more advantages of stability at a high organic solvent concentration $(40 \% \mathrm{v} / \mathrm{v})$, alkaline $\mathrm{pH}$ $(10 \mathrm{pH})$, and thermostability $\left(60^{\circ} \mathrm{C}\right)$. These properties make enzyme suitable for detergent and synthetic biology application. Our results are also compared with some published research articles in various journals, data is shown in Table 4 . The comparison is based on only carbon and nitrogen sources used. The full comparison is not possible due to the difference in media composition, protease activity unit, strains, and other fermentation conditions. In available literature, most of the researchers have performed fermentation in the basal medium using pure sugars (glucose, sucrose, and starch) and expensive nitrogen sources (peptone, yeast extract, albumin, and casamino acids), as shown in Table 4. Our results show that bacterial growth and protease titer have certainly had no difference when yeast extract or corn steep liquor was used as nitrogen source (Figure 3). About $90 \%$ of nitrogen source cost was saved when yeast extract was replaced with corn steep liquor. In addition, scale-up experiments proved the practical potential of new thermophilic and organo-solvent tolerant strain for industrial scale protease production using cost-effective carbon and nitrogen sources.

\section{Conclusion}

Organo-solvent tolerant and thermophilic strain was isolated and identified as Bacillus sp. BBXS-2, the strain was hyper protease producing that was stable in a high concentration of organic solvents. Protease fermentation was scaled up in a $2 \mathrm{~L}$ conical flask with a titer of $6723 \mathrm{U} / \mathrm{mL}$ under optimized fermentation conditions (molasses, corn steep liquor, $\mathrm{pH} 9.0$, and $45^{\circ} \mathrm{C}$ ). In addition, results showed that bacterial growth and protease titer have certainly no difference when yeast extract or corn steep liquor was used as nitrogen source. About $90 \%$ of nitrogen source cost was saved when yeast extract was replaced with corn steep liquor. The extracellular enzyme was purified and partially characterized. Purified protease displayed excellent tolerance towards alkaline $\mathrm{pH}(8.0-12.0)$, temperature $\left(60^{\circ} \mathrm{C}\right)$, organic solvents $(40 \% \mathrm{v} / \mathrm{v})$, surfactants and oxidizing \& bleaching agents. Results suggest that strain possess practical potential to be used in industrial production unit and an enzyme having excellent properties which make it suitable for biotechnological applications. 


\section{Acknowledgment}

Funding was provided by the Natural Science Foundation of China (No.31300603), Program for Professor of Special Appointment (Eastern Scholar) at Shanghai Institutions of Higher Learning (No. 2012-28), Fundamental Research Funds for the Central Universities (No. 15D110527, No.15D110508, No.13D110522, No. 15D110568, No. 15D310523, No. 15D110568), the National College Student Innovation Experiment Program (No. 14T10501), General Financial Grant from the China Postdoctoral Science Foundation (2015M571455).

\section{Conflict of Interest}

The authors declare no competing interests.

\section{References}

1. Kumar CG, Takagi H (1999) Microbial alkaline proteases: from a bioindustrial viewpoint. Biotechnol Adv 17: 561-594.

2. Pillai P, Mandge S, Archana G (2011) Statistical optimization of production and tannery applications of a keratinolytic serine protease from Bacillus subtilis P13. Process Biochem 46: 1110-1117.

3. Gupta R, Beg QK, Khan S, Chauhan B (2002) An overview on fermentation, downstream processing and properties of microbia alkaline proteases. Appl Microbiol Biotechnol 60: 381-395.

4. Thangam EB, Rajkumar GS (2002) Purification and characterization of alkaline protease from Alcaligenes faecalis. Biotechnol Appl Biochem 35: 149-154.

5. Qureshi AS, Bhutto MA, Khushk I, Dahot MU (2013) Optimization of cultural conditions for protease production by Bacillus subtilis EFRL 01 . Afr J Biotechnol 10: 5173-5181.

6. Lin X, Lee CG, Casale ES, Shih JC (1992) Purification and characterization of a keratinase from a feather-degrading Bacillus licheniformis strain. Appl Environ Microb 58: 3271-3275.

7. Cheng SW, Hu HM, Shen SW, Takagi H, Asano M, et al. (1995) Production and characterization of keratinase of a feather-degrading Bacillus licheniformis PWD-1. Biosci Biotechnol Biochem 59: 2239-2243.

8. Rozs M, Manczinger L, Vágvölgyi Cs, Kevei F, Hochkoeppler A, et al. (2001) Fermentation characteristics and secretion of proteases of a new keratinolytic strain of Bacillus licheniformis. Biotechnol Lett 23: 1925-1929.

9. Kojima M, Kanai M, Tominaga M, Kitazume S, Inoue A, et al. (2006) Isolation and characterization of a feather-degrading enzyme from Bacillus pseudofirmus FA30-01. Extremophiles 10: 229-235.

10. Evans KL, Crowder J, Miller ES (2000) Subtilisins of Bacillus spp. hydrolyze keratin and allow growth on feathers. Can J Microbiol 46: 1004-1011.

11. Doukyu N, Ogino H (2010) Organic solvent-tolerant enzymes. Biochem Eng J 48: 270-282.

12. Badoei-Dalfard A, Karami (2013) Screening and isolation of an organic solvent tolerant-protease from Bacillus sp. JER02: activity optimization by response surface methodology. J Mol Catal B-Enzym 89: 15-23.

13. Li S, He BF, Bai Z, Ouyang P (2009) A novel organic solvent-stable alkaline protease from organic solvent-tolerant Bacillus licheniformis YP1A. J Mol Catal B-Enzym 56: 85-88.

14. Tang XY, Pan Y, Li S, He BF (2008) Screening and isolation of an organic solvent-tolerant bacterium for high-yield production of organic solventstable protease. Bioresour Technol 99: 7388-7392.

15. Geok LP, Razak CAN, Rahaman RNZRA, Salleh AB (2003) Isolation and screening of an extracellular organic solvent-tolerant protease producer Biochem Eng J 13: 73-77.

16. Isken S, de Bont JA (1998) Bacteria tolerant to organic solvents. Extremophiles 2: 229-238.
17. Kim K, Lee S, Lee K, Lim D (1998) Isolation and characterization of toluene-sensitive mutants from the toluene-resistant bacterium Pseudomonas putida GM73. J Bacteriol 180: 3692-3696.

18. Ogino H, Watanabe F, Yamada M, Nakagawa S, Hirose T, et al. (1999) Purification and characterization of organic solvent-stable protease from organic solvent-tolerant Pseudomonas aeruginosa PST-01. J Biosci Bioeng 87: 61-68.

19. Rahman RNZRA, Geok LP, Basri M, Salleh AB (2006) An organic solvent-stable alkaline protease from Pseudomonas aeruginosa strain $\mathrm{K}$ : Enzyme purification and characterization. Enzyme Microb Technol 39: 1484-1491.

20. Ogino H, Ishikawa H (2001) Enzymes which are stable in the presence of organic solvents. J Biosci Bioeng 91: 109-116.

21. Gupta A, Roy I, Khare SK, Gupta MN (2005) Purification and characterization of a solvent stable protease from Pseudomonas aeruginosa PseA. J Chromatogr A 1069: 155-161.

22. Gupta A, Singh R, Khare SK, Gupta MN (2006) A solvent tolerant isolate of Enterobacter aerogenes. Bioresour Technol 97: 99-103.

23. Paje ML, Neilan BA, Couperwhite I (1997) A Rhodococcus species that thrives on medium saturated with liquid benzene. Microbiology 143: 2975-2981.

24. Karan R, Singh SP, Kapoor S, Khare SK (2011) A novel organic solvent tolerant protease from a newly isolated Geomicrobium sp. EMB2 (MTCC 10310): production optimization by response surface methodology. N Biotechnol 28: 136-145.

25. Açıel Ü, Erșan M, Açıkel YS (2010) Optimization of critical medium components using response surface methodology for lipase production by Rhizopus delemar. Food Bioprod Process 88: 31-39.

26. Lin ES, Sung SC (2006) Cultivating conditions influence lipase production by the edible Basidiomycete Antrodia cinnamomea in submerged culture. Int J Food Microbiol 39: 98-102.

27. Penner D, Ashton FM (1967) Hormonal control of proteinase activity in squash cotyledons. Plant Physiol 42: 791-796.

28. Tamura K, Stecher G, Peterson D, Filipski A, Kumar S (2013) MEGA6: molecular evolutionary genetics analysis version 6.0. Mol Biol Evol 30: 2725-2759.

29. Maddipati P, Atiyeh HK, Bellmer DD, Huhnke RL (2011) Ethanol production from syngas by Clostridium strain P11 using corn steep liquor as a nutrient replacement to yeast extract. Bioresour Technol 102: 6494-6501.

30. Ibrahim AS, Alsalamah AA, Elbadawi Y, Eltayeb MA, Ibrahim SSS (2015) Production of extracellular alkaline protease by new halotolerant alkaliphilic Bacillus sp. NPST-AK15 isolated from hyper saline soda lakes. Electron J Biotechno 18: 236-243.

31. Satishkumar R, Ananthan G, Arun J (2015) Production, purification and characterization of alkaline protease by ascidian associated Bacillus subtilis GA CAS8 using agricultural wastes. Biocatal Agric Biotechnol 4: 214-220.

32. Qureshi AS, Zhang J, Bao J (2015) High ethanol fermentation performance of the dry dilute acid pretreated corn stover by an evolutionarily adapted Saccharomyces cerevisiae strain. Bioresour Technol 189: 399-404.

33. Parrado J, Rodriguez-Morgado B, Tejada M, Hernandez T, Garcia C (2014) Proteomic analysis of enzyme production by Bacillus licheniformis using different feather wastes as the sole fermentation media. Enzyme Microb Technol 57: 1-7.

34. Oliveira F, Moreira C, Salgado JM, Abrunhosa L, Venâncio A, et al. (2016) Olive pomace valorization by Aspergillus species: lipase production using solid-state fermentation. J Sci Food Agric 96: 3583-3589.

35. Vijayaraghavan P, Lazarus S, Vincent SG (2014) De-hairing protease production by an isolated Bacillus cereus strain AT under solid-state fermentation using cow dung: Biosynthesis and properties. Saudi J Biol Sci 21: 27-34.

36. Mukherjee AK, Adhikary H, Rai S (2008) Production of alkaline protease by a thermophilic Bacillus subtilis under solid-state fermentation (SSF) 
Citation: Qureshi AS, Simair AA, Ali CH, Khushk I, Khokhar JA, et al. (2018) Production, Purification and Partial Characterization of OrganoSolvent Tolerant Protease from Newly Isolated Bacillus sp. BBXS-2. Ferment Technol 7: 151. doi:10.4172/2167-7972.1000151

Page 9 of 9

condition using Imperata cylindrica grass and potato peel as low-cost medium: characterization and application of enzyme in detergent formulation. Biochem Eng J 39: 353-361.

37. Singh AK, Singh S, Tripathi V, Garg SK (2011) A novel psychrotrophic, solvent tolerant Pseudomonas putida SKG-1 and solvent stability of its psychro-thermoalkalistable protease. Process Biochem 46: 1430-1435.

38. Yao C, Cao Y, Wu S, Li S, He BF (2013) An organic solvent and thermally stable lipase from Burkholderia ambifaria YCJ01: purification, characteristics and application for chiral resolution of mandelic acid. J Mol Catal B-Enzym 85: 105-110.

39. Li X, Yu HY (2012) Purification and characterization of an organicsolvent-tolerant cellulase from a halotolerant isolate, Bacillus sp. L1. J Ind Microbiol Biotechnol 39: 1117-1124.
40. Foukis A, Stergiou PY, Theodorou LG, Papagianni M, Papamichael EM (2012) Purification, kinetic characterization and properties of a novel thermo-tolerant extracellular protease from Kluyveromyces marxianus IFO 0288 with potential biotechnological interest. Bioresour Technol 123: 214-220.

41. Jain D, Pancha I, Mishra SK, Shrivastav A, Mishra S (2012) Purification and characterization of haloalkaline thermoactive, solvent stable and SDS-induced protease from Bacillus sp.: a potential additive for laundry detergents. Bioresour Technol 115: 228-236. 